\title{
Total replacement of fish oil by soybean or linseed oil with a return to fish oil in Turbot (Psetta maxima) 2. Flesh quality properties
}

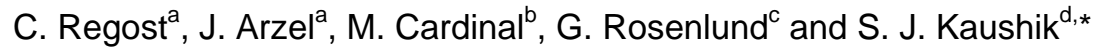

a Fish Nutrition Laboratory, Unité mixte INRA-IFREMER, Centre de Brest IFREMER, 29280 Plouzané, France b Food Engineering Laboratory, IFREMER Centre de Nantes, BP 21105, 44311, Nantes, France

c Nutreco, Aquaculture Research Centre (ARC), P.O. Box 48, 4001, Stavanger, Norway

d Fish Nutrition Laboratory, Unité mixte INRA-IFREMER, 64310 Saint Pée-sur-Nivelle, France

*: Corresponding author :kaushik@st-pee.inra.fr

\begin{abstract}
:
The aim of this study was to evaluate (1) the effects of replacement of fish oil by vegetable oils on flesh quality and (2) the effects of a washout with a return to fish oil on flesh quality of turbot. In a first period of 3 months, three isonitrogenous and isolipidic diets containing $9 \%$ of added marine fish oil (FO), soybean oil (SO) or linseed oil (LO) were fed to triplicate groups of 25 marketable size turbot (initial body weight: $579 \pm 1 \mathrm{~g}$ ) grown in sea water at the temperature of $17^{\circ} \mathrm{C}$. At the end of the first period, all groups of turbot were fed with the diet containing fish oil (diet FO) for a further period of 2 months. The gutted and fillet yields were not affected by the incorporation of vegetable oils. However, soybean or linseed oils significantly affected the organoleptic quality of flesh particularly odour, colour and texture. A more pronounced potatoes odour and a lower fat texture were observed in dorsal fillet of turbot fed soybean oil diet. During the washout period, the differences observed between treatments in first period on sensory attributes disappeared. This study showed that the changes in organoleptic properties occurring due to the intake of vegetable oils can be reduced with a return to a fish-oil-based diet.
\end{abstract}




\section{INTRODUCTION}

Incorporation of vegetable oils in diets is known to influence the nutritional quality of fish flesh in salmonids (Reinitz and Yu, 1981; Hardy et al., 1987; Arzel et al., 1994; Skonberg et al., 1994) and in marine fish like gilthead bream, European sea bass or turbot (Kalogeropoulos et al. 1992; Bell et al., 1994; 1999; Yildiz and Sener, 1997). Fatty acid composition of fish flesh generally reflects dietary fatty acid composition (Dosanjh et al., 1988, 1998; Greene and Selivonchick, 1990). In fact, the substitution of vegetable oils for fish oil induced an increase of linoleic acid in case of soybean or rapeseed oils or an increase of linolenic acid in case of linseed oil and consequently a decrease of highly unsaturated fatty acids (Mugrditchian et al., 1981; Greene and Selivonchick, 1990; Sowizral et al., 1990; Bell et al., 1994), known for their health benefits in humans (De Deckere et al., 1998; Sargent and Tacon, 1999; Sargent et al., 2001).

Available data on the effects of dietary fat sources on organoleptic qualities of the flesh of cultured fish are often contradictory. Soybean oil in diets did not significantly affect taste of flesh of brook charr (Guillou et al., 1995) or flesh flavour of Atlantic salmon (Hardy et al., 1987) whereas significant effects of soybean oil were observed on odour, taste and colour intensity in Atlantic salmon (Thomassen and Røsjø, 1989). In turbot, to our knowledge, no study has reported the effects of vegetable oils on parameters of flesh quality except the study of Sérot et al. (2001) on volatile aroma compounds.

In an earlier study (Regost et al. 2002, in press), we reported the effects of dietary vegetable oils and of a wash-out with fish oil on growth performance and fatty acid composition of turbot. Here, we present data related to physical and organoleptic quality of flesh. 


\section{MATERIAL AND METHODS}

\subsection{Experimental diets}

Three isonitrogenous and isolipidic practical diets were formulated to contain $9 \%$ of fish oil (FO), soybean oil (SO) or linseed oil (LO). Diets were manufactured industrially (Aquaculture Research Centre, Stavanger, Norway). Ingredient and chemical compositions of the diets are reported in Table 1 and the principal fatty acid composition in Table 2. For further description of the diets, see Regost et al. (2002, in press).

\subsection{Growth trial}

The growth trial was conducted in the experimental facilities of IFREMER (Brest, France) at a constant seawater temperature of $17 \pm 0.5^{\circ} \mathrm{C}$ with a salinity of $35 \%$ in a flow through system for a period of 13 weeks. Twenty-five turbot, Psetta maxima, having a mean initial body weight of $579 \pm 10 \mathrm{~g}$ (mean $\pm \mathrm{sd}$ ) were randomly allotted to each tank ( $1 \mathrm{~m}^{3}$ tank with a water flow rate of $14 \mathrm{l} \cdot \mathrm{min}^{-1}$ ) and a 12/12h light/dark cycle was adopted. The three experimental diets were each randomly allocated to triplicate groups which were fed by hand once a day to visual satiety.

\subsection{Washout with fish oil}

At the end of growth trial and after samplings, there were 12 fish per tank having a mean individual body weight of $882 \pm 17 \mathrm{~g}$. All groups of turbot were fed with diet FO for a period of 8 weeks. At the end of this period, each group of fish was weighed and sampled. 


\subsection{Samplings}

At the end of growth trial, the same protocol of slaughter was strictly applied to all groups. Fish were fasted two days before slaughtering. Fish were stunned and bled to death in cold water before dissection. After slaughter, gutting was done immediately and filleting (four fillets: dorsal-ventral and inferior-superior fillets) was done within $30 \mathrm{~min}$. Three fish (fillets with skin) per tank were withdrawn for sensory analyses and two fish (fillets without skin) per tank for instrumental texture analyses. At the end of the finishing trial, four fish per tank were withdrawn (fillets with skin) for sensory analyses.

\subsection{Flesh quality evaluation}

Sensory profiling (Stone et al., 1974; ISO 11035) was performed two days after slaughtering on dorsal and ventral cooked fillets by an internal sensory panel (IFREMER, Nantes, France) consisting of 20 individuals selected for their interest, availability and sensorial capacities of memorising stimuli or discriminating intensities. All were volunteers and received regular training sessions to develop their sensory performances and knowledge of marine products. Sessions were conducted in an air-conditioned room designed for sensory analysis divided into ten individual boxes with standardized light $\left(\mathrm{T}=6500^{\circ} \mathrm{K}\right)$ and equipped with a computerised system (Fizz Biosystèmes, Dijon, France). These conditions were conducive to concentration and avoided communication between assessors and disturbance by external factors (AFNOR , 1995). The samples with skin were cooked for $2.5 \mathrm{~min}$ in a microwave oven (Panasonic NN8550, 850W) in closed bowl before analyses. Products were assigned 3digit numbers, randomised and served simultaneously. The samples were evaluated using a continuous scale presented on a computer screen from 0 (low intensity) to 10 (high intensity) for the following attributes: intensity, potatoes, fatty fish, marine-iodine and milky for odour; whiteness and fatness for visual aspect; intensity, fatty fish, marine-iodine, sweet, acid flavour 
and bitter aftertaste for flavour; and firmness, elasticity, moisture, fat, exudation and sticky for texture in mouth. The odour and aspect attributes were assessed immediately after opening the bowl, while the flavour and texture in mouth attributes were evaluated after cutting the samples. Data were immediately transferred to a central computer for statistical treatment.

\subsection{Instrumental texture analyses}

Instrumental texture analyses were performed at INRA (Rennes, France) on raw fillets 7 days after slaughter, on fillets kept in ice in sealed vacuum packing at $4^{\circ} \mathrm{C}$. A Kramer shear press $(64 \mathrm{~mm} \times 64 \mathrm{~mm})$ was used with compression up to breaking using a universal testing machine (INSTRON, model 5544) with a load cell of $5 \mathrm{kN}$ and during this test, a constant speed of 1 $\mathrm{mms}^{-1}$ into the fillets was adopted. Samples were withdrawn from the caudal part of fish and measured $64 \mathrm{~mm}$ long and fillet size in width. The weight of each Kramer sample was recorded to avoid possible size differences (Szczesniack et al., 1970). The pH of fillets was measured using a pH meter on minced muscle. The instrumental analyses followed procedures described by Laroche et al. (1996).

\subsection{Statistical analysis}

The data of yields, $\mathrm{pH}$ and instrumental texture analyses were subjected to one-way analysis of variance to test the effects of experimental diets. In cases where significant differences occurred (significance level $=0.05$ ), the Newman-Keuls test was used to compare the means. These statistical tests were performed using the STAT-ITCF (1998) software. The results of sensory analyses were subjected to two-way analysis of variance to test the effects of experimental diets and assessors. In cases where significant differences occurred, the means were compared using Duncan test with the FIZZ, Biosystèmes software (Dijon, France). 


\section{RESULTS}

\subsection{Effects of dietary oil sources}

Although gutted yield were very high in turbot $(>0.90)$, fillet yield were very low near 0.26. There was no significant difference in the gutted and fillet yields of turbot fed the different oil sources.

Sensory analyses were performed on dorsal and ventral fillets separately (Tables 3 and 4). On dorsal fillets, potatoes odour was more pronounced in fillets of turbot fed diet SO than in the other groups. Odour of fish fed diet FO was more intense than that of the other groups but not different statistically $(\mathrm{P}=0.08)$. No significant difference was observed in the attributes of aspect and flavour of dorsal fillets. Concerning texture in mouth, flesh moisture of fish fed diet SO and diet LO were inferior to those of fish fed diet FO. Fat texture was significantly different among groups, fish fed diet FO having a fatter texture. For exudation, fish fed diet LO had the lowest value while those fed diet SO had the highest value. On ventral fillets, only attributes of odour presented significant differences among treatments (Table 4). Intensity and fat fish odour were more pronounced in fillets of fish fed diet LO and the values of these fish were different than those of fish fed diet FO. Milky odour was stronger in fish fed diet LO than in those fed diet SO. On dorsal and ventral fillets, the marine flavour appeared to be more pronounced in turbot fed linseed oil but the values were not statistically different $(\mathrm{P}=$ 0.07 and 0.08 , respectively).

The measures of $\mathrm{pH}$ in flesh were not statistically different between treatments (Table 5). The instrumental texture analyses were performed on the four fillets per fish. The values of 
maximal force were high, but there were no significant differences between treatments and between the different fillet position $(\mathrm{P}>0.05)$.

\subsection{Effects of finishing with fish oil}

In the second part on the experimentation, all fish were fed the fish-oil based diet (FO). Sensory analyses of dorsal and ventral fillets are reported in Tables 6 and 7, respectively. In dorsal muscle, there was no difference among treatments in the attributes of odour and visual aspect. Fillets of turbot fed only diet FO had a fatty fish flavour significantly more pronounced than in those previously fed diet LO. Fillets of fish fed only diet FO were less firm than those of fish fed previously diet SO. Texture in mouth of fish fed diet SO and then diet FO had lower moisture than in the other groups. In ventral fillets, no difference was found for attributes of odour and texture in mouth (Table 7). Fatty aspect appeared lower in fish fed previously diet LO than in the other groups. Sweet flavour of fish fed only diet FO was significantly different than those of fish fed diet LO previously. The instrumental texture analyses were not made in the finishing period.

\section{DISCUSSION}

Slaughter and fillet yields of turbot were not significantly affected by the addition of vegetable oils in diets, and the values were similar to those found by Regost et al. (2001). The inclusion of soybean or linseed oils in diets however influenced the organoleptic properties of the flesh of turbot particularly with regard to parameters of odour and texture. The incorporation of soybean oil in diet of turbot induced on dorsal fillets a more pronounced 
potatoes odour, a lower fat texture and a higher exudation than in fish fed diet with fish oil. The replacement of fish oil by linseed oil also led to a lower fat texture of dorsal and ventral fillets, a more intense odour and a high fatty fish odour compared to fish fed diet with fish oil. With the same diets, it was observed earlier that the volatile aromatic compounds and also the odour descriptors varied according to oil sources due to the variation of muscle fatty acid profile, which reflected those of the diet (Sérot et al., 2001; Regost et al., in press). Sérot et al. (2001) described turbot odour in terms of fatty fish, fresh fish or milky descriptors very similar to the attributes used in the present study. The differences perceived here in texture in mouth of dorsal fillets were often of low range and were not observed in ventral fillets or with the instrumental analyses. This is attributable to the very low fat content in turbot muscle (1.5\% in wet weight), which is also not significantly affected by dietary oil sources (Regost et al., 2002, in press) and by the size of the ventral muscle (smaller and thinner). The more pronounced odour of ventral fillets than the odour of dorsal fillets could also be due to the relatively higher fat content of ventral fillet (2.2\% of wet weight, Regost et al., in press), lipids being known to participate in the flavour characteristics of fish flesh. The effects of dietary vegetable oils on organoleptic properties are also sometimes contradictory. In brook charr, Guillou et al. (1995) found no significant difference in taste but found that texture of fish fed soybean oil was less firm than those of fish fed a diet containing fish oil. Arzel et al. (1994) found that brown trout fed with corn oil had a fattier texture in mouth than trout fed with fish oil. On the other hand, Thomassen and Røsjø (1989) observed in rainbow trout, differences in taste, odour and colour in fish fed a diet containing soybean oil, the results of colour on sensory analyses being confirmed by instrumental data. Similar observations were made by Waagbø et al. (1993) in Atlantic salmon fed a diet containing rapeseed oil. No difference and no relationship were found between sensory quality parameters and dietary fat sources by Boggio et al. (1985) in rainbow trout or by Hardy et al. (1987) and Koshio et al. 
(1994) in Atlantic salmon fed diets containing fish or vegetable oils. Indeed, it is difficult to compare the organoleptic properties reported in different studies, since a number of parameters vary: different levels of inclusion of vegetable oils in the diets, methods of cooking or storage, time interval between slaughter and analyses, besides differences in age or species of fish. Moreover, since sensory analyses were conducted on cooked samples, taste and aroma differences may be more difficult to detect than in raw samples (Skonberg et al., 1993).

In the second part of the experimentation (finishing trial), all fish were fed the same fish oil based diet during eight weeks. With regard to organoleptic properties, there was no difference in the attributes of odour and the differences found at the end of the first period disappeared after two months on the fish oil diet. Dorsal fillets of fish fed only the FO diet had a more pronounced fatty fish flavour and a lower firmness than the fish fed vegetable oils previously. The higher muscle fat content of ventral fillets could explain the stronger fat aspect, observed in fish fed only FO diet (Regost et al., 2002, in press). The criteria for which significant differences occurred were not the same at the end of the finishing trial as at the end of the growth trial. The characteristics, which may be previously attributed to dietary sources, were not recognised at the end of the washout period with the fish oil based diet. This suggests that, although the fatty acid composition is not completely restored (Regost et al. 2002, in press), flesh quality attributes are generally restored after two months of recovery with a fish oil based diet.

\section{CONCLUSION}


Three months of feeding turbot with diets containing vegetable oils led to changes in some of the organoleptic properties of the flesh. On subsequent feeding with a fish-oil based diet, the differences between treatments, in terms of organoleptic properties observed previously disappeared. It seems thus possible to reduce the effects on organoleptic properties observed in turbot fed dietary vegetable oils by a return to diets containing only fish oil, two months before harvest.

\section{ACKNOWLEDGEMENTS}

ARC (Norway) and IFREMER (France) financially supported this study. The authors would like to express their gratitude to Florence Lefebvre and Benoît Fauconneau (INRA, Rennes, France) for their assistance for the texture analyses. C. Regost was a recipient of a scholarship from Région Bretagne (France) and IFREMER. 


\section{REFERENCES}

AFNOR, 1995. Directives générales pour l'implantation de locaux destinés à l'analyse sensorielle (NF V 09-105). In: Contrôle de la qualité des produits alimentaires, analyse sensorielle, 5ème édition AFNOR, Paris La Défense, 115-127.

Arzel, J., Martinez Lopez, F.X., Métailler, R., Stéphan, G., Viau, M., Gandemer, G., Guillaume, J., 1994. Effect of dietary lipid on growth performance and body composition of brown trout (Salmo trutta) reared in seawater. Aquaculture 123, 361375.

Bell, J.G., Tocher, D.R., MacDonald, F.M., Sargent, J.R., 1994. Effects of diets rich in linoleic (18:2n-6) and $\alpha$-linonenic (18:3n-3) acids on growth, lipid class and fatty acid compositions and eicosanoid production in juvenile turbot (Scophtalmus maximus L.). Fish Physiol. Biochem. 13, 105-118.

Bell, J.G., Tocher, D.R., Farndale, B.M., McVicar, A.H., Sargent, J.R., 1999. Effects of essentiel fatty acid-deficient diets on growth, mortality, tissue histopathology and fatty acid compositions in juvenile turbot (Scophtalmus maximus). Fish Physiol. Biochem. 20, 263-277.

Boggio, S.M., Hardy, W.H., Babbitt, J.K., Brannon, E.L., 1985. The influence of dietary lipid source and alpha-tocopheryl acetate level on product quality of rainbow trout (Salmo gairdneri). Aquaculture 51, 13-24.

De Deckere, E.A., Korver, O., Verschuren, P.M., Katan, M.B., 1998. Health aspects of fish and n-3 polyunsaturated fatty acids from plant and marin origin. Eur. J. Clin. Nutr. 52, 749-753.

Dosanjh, B.S., Higgs, D.A., Plotnokoff, M.D., Markert, J.R., Buckley, J.T., 1988. Preliminary evaluation of canola oil, pork lard and marine lipid singly and in combination as 
supplemental dietary lipid sources for juvenile fall chinook salmon (Oncorhynchus tshawytscha). Aquaculture 68, 325-343.

Dosanjh, B.S., McKenzie, D.J., Randall, D.J., Eales, J.G., Rowshandeli, N., Rowshandeli, M., Deacon, G., 1998. Influence of dietary blends of menhaden oil and canola oil on growth, muscle lipid composition and thyroidal status of Atlantic salmon (Salmo salar) in sea water. Fish Physiol. Biochem. 19, 123-134.

Greene, D.H.S., Selivonchick, D.P., 1990. Effects of dietary vegetable, animal and marine lipids on muscle lipid and hematology of rainbow trout (Oncorhynchus mykiss). Aquaculture 89, 165-182.

Guillou, A., Soucy, P., Khalil, M., Adambounou, L., 1995. Effects of dietary vegetable and marine lipid on growth, muscle fatty acid composition and organoleptic quality of flesh of brook charr (Salvelinus fontinalis). Aquaculture 136, 351-362.

Hardy, R.W., Scott, T.M., Harrell, L.W., 1987. Replacement of herring oil with menhaden oil, soybean oil, or tallow in the diets of Atlantic salmon raised in marine net-pens. Aquaculture 65, 267-277.

ITCF, 1988. STAT-ITCF, 4 ème éd. Service des Etudes Statistiques, Paris, France.

Kalogeropoulos, N. Alexis, M.N, Henderson, R.J., 1992. Effects of dietary soybean and cod liver oil levels on growth and body composition of gilthead bream (Sparus aurata). Aquaculture 104, 293-308.

Koshio, S., Ackman, R.G., Lall, S.P., 1994. Effects of oxidized herring and canola oils in diets on growth, survival and flavor of Atlantic salmon, Salmo salar. J. Agric. Food Chem. 42, 1164-1169.

Laroche, M., Bonnet, S., Fauconneau, B., Marcel, J., 1996. Evolution post mortem de quelques caractéristiques de la chair de truite fario (Salmo trutta) et de carpe (Cyprinus 
carpio). Proceedings « Refrigeration Science and Technology », Refrigeration and Aquaculture, Bordeaux, France, 117-125.

Mugrditchian, D.S., Hardy, R.W., Iwaoka, W.T., 1981. Linseed oil and animal fat as alternative lipid sources in dry diets for chinook salmon (Oncorhynchus tshawytscha). Aquaculture 25, 161-172.

Regost, C., Arzel, J., Cardinal, M., Robin, J., Laroche, M. and Kaushik, S.J., 2001. Dietary lipid level, hepatic lipogenesis and flesh quality in turbot (Psetta maxima). Aquaculture 193, 291-309.

Regost, C., Arzel, J., Robin, J., Rosenlund, G., Kaushik, S.J., 2002. Total replacement of fish oil by soybean or linseed oil with a return to fish oil in turbot (Psetta maxima). I. Growth performance, fatty acid profile and lipid metabolism. Aquaculture (in press).

Reinitz, G.L., Yu, T.C., 1981. Effects of dietary lipids on growth and fatty acid composition of rainbow trout (Salmo gairdneri). Aquaculture 35, 19-27.

Sargent, J.R., Tacon, A.G.J., 1999. Development of farmed fish: a nutritionally necessary alternative to meat. Proc. Nutr. Soc. 58, 377-383.

Sargent, J.R., Bell, J.G., McGhee, F., McEvoy, J., Webster, J.L., 2001. The nutritional value of fish. In: Kestin S.C., Warriss, P.D. (Eds), Farmed Fish Quality, Bristol, U.K., pp. 312.

Sérot, T., Regost, C., Prost, C., Robin, J., Arzel, J., 2001. Effect of dietary lipid sources on odor-active compounds in muscle of turbot (Psetta maxima). J. Sci. Food Agric. 81, 1339-1346.

Skonberg, D.I., Rasco, B.A., Dong, F.M., 1993. Effects of feeding high monounsaturated sunflower oil diets on sensory attributes of salmonid fillets. J. Aquatic Food Product Tech. 2, 117-133. 
Skonberg, D.I., Rasco, B.A., Dong, F.M., 1994. Fatty acid composition of salmonid muscle changes in response to a high oleic acid diet. J. Nutr. 124, 1628-1638.

Sowizral, K.C., Rumsey, G.L., Kinsella, J.E., 1990. Effect of dietary $\alpha$-linolenic acid on n-3 fatty acids of rainbow trout lipids. Lipids 25, 246-253.

Stone, H., Sidel, J.L., Oliver, S., Woolsey, A., Singleton, R.C., 1974. Sensory evaluation by quantitative descriptive analysis. Food Tech. 28 , 24-34.

Szczesniack, A.S., Humbaugh, P.R., Block, H.W., 1970. Behaviour of different foods in the standard shear compression cell of the shear press and the effect of sample weight on peak area and maximum force. J. Texture Studies 1, 356-378.

Thomassen, M.S., Røsjø, C., 1989. Different fats in feed for salmon: influence on sensory parameters, growth rate and fatty acids in muscle and heart. Aquaculture 79, 129-135.

Waagbø, R., Sandnes, K., Torrissen, O.J., Sandvin, A., Lie, Ø., 1993. Chemical and sensory evaluation of fillets from Atlantic salmon (Salmo salar) fed three levels of N-3 polyunsaturated fatty acids at two levels of vitamin E. Food Chem. 46, 361-366.

Yildiz, M., Sener, E., 1997. Effect of dietary supplementation with soybean oil, sunflower oil or fish oil on the growth of seabass (Dicentrarchus labrax L.). Workshop of the CIHEAM Network on Technology of Aquaculture in the Mediterranean, 24-26 June 1996, Zaragoza, Spain, 9 pp. 
Table 1. Ingredients and proximate composition of the experimental diets.

\begin{tabular}{lccc}
\hline & Experimental diets & & \\
\cline { 2 - 4 } & FO & SO & LO \\
\hline Ingredients $(\mathrm{g} / \mathrm{kg})$ & & 500 & 500 \\
Fish meal (Norseamink) & 500 & 50 & 50 \\
Soluble fish protein concentrate (CPSP, & 50 & - & - \\
Sopropêhe, France) & & 90 & - \\
Marine fish oil & 90 & - & 90 \\
Soybean oil & - & 183 & 183 \\
Linseed oil & - & 147 & 147 \\
Whole wheat & 183 & 20 & 20 \\
Wheat gluten & 147 & 10 & 10 \\
Mineral + vitamin mixes ${ }^{\text {a }}$ & 20 & & \\
Binder + yttrium oxide & 10 & 90.2 & 90.3 \\
Proximate composition & & 9.1 & 9.1 \\
Dry matter (DM),\% & 89.1 & 57.6 & 57.6 \\
Ash (\% DM) & 9.2 & 16.5 & 16.5 \\
Crude protein (\% DM) & 57.4 & 23.4 & 23.1 \\
Crude fat (\% DM) & 16.6 & & \\
Gross energy (kJ/g DM) & 23.5 & & \\
\hline
\end{tabular}

${ }^{a}$ Proprietary mixtures (Nutreco, ARC) providing levels meeting requirements as proposed by NRC (1993) 
Table 2. Main fatty acid composition of experimental diets (\% of methyl esters)

\begin{tabular}{lccc}
\hline & \multicolumn{3}{c}{ Experimental diets } \\
\cline { 2 - 4 } Fatty acids (FA) & FO & SO & LO \\
\hline N Saturated FA & $\mathbf{2 2 . 5}$ & $\mathbf{1 8 . 5}$ & $\mathbf{1 4 . 3}$ \\
18:1 n-9 & 11.9 & 17.1 & 15.0 \\
$22: 1 n-11$ & 15.1 & 4.3 & 3.3 \\
$\sum$ Monounsaturated FA & $\mathbf{4 7 . 1}$ & $\mathbf{2 9 . 8}$ & $\mathbf{2 5 . 5}$ \\
18:2n-6 & 5.2 & 35.6 & 15.5 \\
20:4n-6 & 0.5 & 0.3 & 0.2 \\
$\sum$ n-6 FA & $\mathbf{6 . 3}$ & $\mathbf{3 6 . 2}$ & $\mathbf{1 6 . 3}$ \\
18:3n-3 & 1.3 & 4.6 & 33.3 \\
20:5n-3 & 7.9 & 3.7 & 3.6 \\
22:6n-3 & 10.6 & 5.6 & 5.5 \\
$\sum$ n-3 FA & $\mathbf{2 4 . 1}$ & $\mathbf{1 5 . 5}$ & $\mathbf{4 3 . 9}$ \\
\hline
\end{tabular}


Table 3. Sensory analyses of dorsal fillets of turbot at the end of growth trial

\begin{tabular}{|c|c|c|c|c|c|}
\hline & \multirow[b]{2}{*}{ Attributes } & \multicolumn{3}{|c|}{ Experimental diets } & \multirow{2}{*}{$\begin{array}{l}\text { ANOVA } \\
\text { P values }\end{array}$} \\
\hline & & FO & $\mathrm{SO}$ & $\mathrm{LO}$ & \\
\hline \multirow{5}{*}{ ODOUR } & intensity & 6.3 & 5.5 & 5.9 & 0.08 \\
\hline & potatoes & $2.0^{\mathrm{b}}$ & $3.1^{\mathrm{a}}$ & $2.1^{\mathrm{b}}$ & 0.002 \\
\hline & fatty fish & 2.3 & 1.8 & 2.1 & 0.40 \\
\hline & marine-iodine & 3.1 & 2.9 & 3.2 & 0.83 \\
\hline & milky & 3.3 & 2.8 & 2.6 & 0.37 \\
\hline \multirow{2}{*}{ ASPECT } & whiteness & 5.0 & 5.7 & 5.4 & 0.32 \\
\hline & fatness & 3.3 & 3.3 & 3.5 & 0.88 \\
\hline \multirow{6}{*}{ FLAVOUR } & intensity & 5.0 & 4.9 & 5.4 & 0.41 \\
\hline & fatty fish & 2.5 & 1.8 & 2.6 & 0.13 \\
\hline & marine & 3.7 & 3.5 & 4.3 & 0.07 \\
\hline & sweet & 1.7 & 1.8 & 1.5 & 0.51 \\
\hline & acid & 0.3 & 0.2 & 0.3 & 0.78 \\
\hline & bitter aftertaste & 0.8 & 0.9 & 0.5 & 0.27 \\
\hline & firmness & 5.1 & 5.5 & 5.9 & 0.06 \\
\hline TEXTURE & elasticity & 4.2 & 4.1 & 4.2 & 0.96 \\
\hline IN & moisture & $5.2^{\mathrm{a}}$ & $4.3^{b}$ & $4.2^{\mathrm{b}}$ & 0.03 \\
\hline \multirow[t]{3}{*}{ MOUTH } & fat & $2.7^{\mathrm{a}}$ & $1.6^{\mathrm{C}}$ & $2.1^{\mathrm{b}}$ & 0.0002 \\
\hline & exudation & $2.8^{\mathrm{ab}}$ & $3.1^{\mathrm{a}}$ & $2.3 b$ & 0.03 \\
\hline & sticky & 2.6 & 2.4 & 2.9 & 0.55 \\
\hline
\end{tabular}

Values in the same row with different superscripts are significantly different $(\mathrm{P}<0.05)$. 
Table 4. Sensory analyses of ventral fillets of turbot at the end of growth trial

\begin{tabular}{|c|c|c|c|c|c|}
\hline & \multirow[b]{2}{*}{ Attributes } & \multicolumn{3}{|c|}{ Experimental diets } & \multirow{2}{*}{$\begin{array}{l}\text { ANOVA } \\
\text { P values }\end{array}$} \\
\hline & & FO & SO & $\mathrm{LO}$ & \\
\hline \multirow{5}{*}{ ODOUR } & intensity & $5.0^{b}$ & $5.6^{\mathrm{ab}}$ & $6.1^{\mathrm{a}}$ & 0.012 \\
\hline & potatoes & 1.5 & 1.7 & 1.7 & 0.91 \\
\hline & fatty fish & $1.4^{\mathrm{b}}$ & $1.9^{\mathrm{ab}}$ & $2.9^{\mathrm{a}}$ & 0.02 \\
\hline & marine-iodine & 2.4 & 2.5 & 2.6 & 0.88 \\
\hline & milky & $2.1^{\mathrm{ab}}$ & $1.6^{\mathrm{b}}$ & $2.4^{\mathrm{a}}$ & 0.03 \\
\hline \multirow{2}{*}{ ASPECT } & whiteness & 5.4 & 4.8 & 4.6 & 0.25 \\
\hline & fatness & 3.0 & 3.3 & 3.3 & 0.67 \\
\hline \multirow{6}{*}{ FLAVOUR } & intensity & 5.2 & 5.1 & 5.2 & 0.99 \\
\hline & fatty fish & 2.6 & 2.5 & 2.3 & 0.69 \\
\hline & marine & 2.4 & 2.8 & 3.4 & 0.08 \\
\hline & sweet & 1.8 & 2.5 & 1.6 & 0.07 \\
\hline & acid & 0.3 & 0.5 & 0.5 & 0.32 \\
\hline & bitter aftertaste & 1.1 & 0.4 & 0.8 & 0.08 \\
\hline & firmness & 5.7 & 5.8 & 5.9 & 0.82 \\
\hline TEXTURE & elasticity & 3.8 & 4.3 & 4.1 & 0.39 \\
\hline IN & moisture & 4.3 & 5.1 & 4.5 & 0.27 \\
\hline \multirow[t]{3}{*}{ MOUTH } & fat & 2.9 & 2.4 & 2.1 & 0.13 \\
\hline & exudation & 2.8 & 3.3 & 3.0 & 0.40 \\
\hline & sticky & 2.4 & 2.5 & 2.9 & 0.35 \\
\hline
\end{tabular}

Values in the same row with different superscripts are significantly different $(P<0.05)$. 
Table 5. $\mathrm{pH}$ and instrumental texture analyses of raw fillets of turbot at the end of growth trial

\begin{tabular}{lccc}
\hline & \multicolumn{3}{c}{ Experimental diets } \\
\cline { 2 - 4 } & FO & SO & LO \\
\hline $\boldsymbol{P H}$ & $6.54 \pm 0.03$ & $6.53 \pm 0.02$ & $6.51 \pm 0.02$ \\
Maximal force $(\mathbf{N} / \mathbf{g})$ & & & \\
Dorsal superior & $58.7 \pm 2.4$ & $52.8 \pm 2.9$ & $59.1 \pm 4.4$ \\
Ventral superior & $60.7 \pm 2.9$ & $56.1 \pm 3.8$ & $59.1 \pm 4.2$ \\
Dorsal inferior & $63.5 \pm 4.3$ & $55.4 \pm 3.9$ & $66.6 \pm 5.6$ \\
Ventral inferior & $68.7 \pm 3.9$ & $59.3 \pm 4.7$ & $68.2 \pm 2.9$ \\
\hline
\end{tabular}

Values are means \pm standard deviation $(\mathrm{n}=6)$.

All values are not significantly different $(P>0.05)$. 
Table 6. Sensory analyses of dorsal fillets of turbot at the end of finishing trial

\begin{tabular}{|c|c|c|c|c|c|}
\hline & \multirow[b]{2}{*}{ Attributes } & \multicolumn{3}{|c|}{ Experimental diets } & \multirow{2}{*}{$\begin{array}{l}\text { ANOVA } \\
\text { P values }\end{array}$} \\
\hline & & FO & $\mathrm{FO}(\mathrm{SO})$ & $\mathrm{FO}(\mathrm{LO})$ & \\
\hline \multirow{5}{*}{ ODOUR } & intensity & 5.6 & 6.1 & 5.7 & 0.28 \\
\hline & potatoes & 3.0 & 3.3 & 2.4 & 0.13 \\
\hline & fatty fish & 2.6 & 2.8 & 2.0 & 0.09 \\
\hline & marine-iodine & 3.4 & 3.2 & 3.4 & 0.81 \\
\hline & milky & 3.4 & 2.4 & 3.0 & 0.09 \\
\hline \multirow{2}{*}{ ASPECT } & whiteness & 6.0 & 5.1 & 5.7 & 0.09 \\
\hline & fatness & 3.7 & 4.0 & 3.4 & 0.09 \\
\hline \multirow{6}{*}{ FLAVOUR } & intensity & 5.7 & 5.5 & 5.2 & 0.30 \\
\hline & fatty fish & $2.7^{\mathrm{a}}$ & $2.2^{\mathrm{ab}}$ & $1.8^{\mathrm{b}}$ & 0.02 \\
\hline & marine & 4.0 & 4.3 & 4.2 & 0.65 \\
\hline & sweet & 2.4 & 2.3 & 2.3 & 0.94 \\
\hline & acid & 0.7 & 0.7 & 0.5 & 0.57 \\
\hline & bitter aftertaste & 0.9 & 0.8 & 0.7 & 0.62 \\
\hline & firmness & $5.0^{b}$ & $6.0^{\mathrm{a}}$ & $5.7^{\mathrm{ab}}$ & 0.04 \\
\hline TEXTURE & elasticity & 4.2 & 3.7 & 3.8 & 0.41 \\
\hline IN & moisture & $4.8^{\mathrm{a}}$ & $3.1^{\mathrm{b}}$ & $4.2^{\mathrm{a}}$ & 0.0001 \\
\hline \multirow[t]{3}{*}{ MOUTH } & fat & 2.9 & 3.0 & 2.6 & 0.28 \\
\hline & exudation & 3.0 & 2.5 & 3.0 & 0.27 \\
\hline & sticky & 2.6 & 2.9 & 2.9 & 0.66 \\
\hline
\end{tabular}

Values in the same row with different superscripts are significantly different $(P<0.05)$. 
Table 7. Sensory analyses of ventral fillets of turbot at the end of finishing trial

\begin{tabular}{|c|c|c|c|c|c|}
\hline & \multirow[b]{2}{*}{ Attributes } & \multicolumn{3}{|c|}{ Experimental diets } & \multirow{2}{*}{$\begin{array}{l}\text { ANOVA } \\
\text { P values }\end{array}$} \\
\hline & & $\mathrm{FO}$ & $\mathrm{FO}(\mathrm{SO})$ & $\mathrm{FO}(\mathrm{LO})$ & \\
\hline \multirow{5}{*}{ ODOUR } & intensity & 5.7 & 5.6 & 5.6 & 0.99 \\
\hline & potatoes & 3.5 & 2.4 & 3.1 & 0.08 \\
\hline & fatty fish & 2.6 & 2.7 & 2.3 & 0.73 \\
\hline & marine-iodine & 3.5 & 3.4 & 3.6 & 0.86 \\
\hline & milky & 2.9 & 2.6 & 3.3 & 0.24 \\
\hline \multirow{2}{*}{ ASPECT } & whiteness & 5.4 & 5.4 & 6.0 & 0.19 \\
\hline & fatness & $3.8^{\mathrm{a}}$ & $3.3^{\mathrm{a}}$ & $2.5^{\mathrm{b}}$ & 0.005 \\
\hline \multirow{6}{*}{ FLAVOUR } & intensity & 5.3 & 5.0 & 5.5 & 0.45 \\
\hline & fatty fish & 2.8 & 2.5 & 2.9 & 0.50 \\
\hline & marine & 4.4 & 4.3 & 4.4 & 0.96 \\
\hline & sweet & $2.2^{\mathrm{b}}$ & $2.5^{\mathrm{ab}}$ & $3.3^{\mathrm{a}}$ & 0.04 \\
\hline & acid & 1.0 & 0.7 & 0.5 & 0.19 \\
\hline & bitter aftertaste & 1.1 & 0.8 & 0.8 & 0.62 \\
\hline & firmness & 5.0 & 5.3 & 5.0 & 0.65 \\
\hline TEXTURE & elasticity & 3.7 & 3.9 & 3.4 & 0.35 \\
\hline IN & moisture & 4.5 & 3.7 & 4.5 & 0.06 \\
\hline \multirow[t]{3}{*}{ MOUTH } & fat & 2.8 & 2.9 & 2.9 & 0.95 \\
\hline & exudation & 2.9 & 2.5 & 2.9 & 0.40 \\
\hline & sticky & 3.3 & 3.1 & 2.7 & 0.39 \\
\hline
\end{tabular}

Values in the same row with different superscripts are significantly different $(P<0.05)$. 